\title{
EUROCRIM 2020*** \\ 20. GODIŠNJA KONFERENCIJA EUROPSKOG UDRUŽENJA ZA KRIMINOLOGIJU 10. - 11. RUJNA 2020., ONLINE IZDANJE
}

Jubilarna dvadeseta godišnja konferencija Europskog udruženja za kriminologiju prvobitno se trebala održati u glavnom gradu Rumunjske, Bukureštu. Međutim, zbog globalne pandemije koronavirusa, konferencija je ipak održana u online izdanju.

Europsko udruženje za kriminologiju (ESC) osnovano je 2000. godine, a cilj udruženja je povezati osobe u Europi koje su aktivno uključene u istraživanje, podučavanje i/ili praksu u području kriminologije. Godišnje ESC-ove konferencije pružaju priliku članovima da predstave rezultate vlastitih istraživačkih projekata, ali i da steknu informacije o projektima i istraživanjima koja se provode u Europi. Na godišnjoj konferenciji saziva se i glavna skupština Udruženja, koja donosi odluke o poslovima Udruženja i daje savjete članovima odbora za njihov predstojeći mandat. U sklopu ovogodišnje konferencije održano je 405 izlaganja na 116 panela, a sudjelovalo je više od 700 stručnjaka iz različitih znanstvenih polja (kriminologija, pravo, psihologija, pedagogija, sociologija...) raspoređenih u 30 ESC-ovih radnih skupina. Premda je broj razumljivo manji nego prethodnih godina, s obzirom na okolnosti u cijelom svijetu, može se reći da je i broj sudionika ove godine pokazao uspješnost konferencije.

Konferenciju je otvorio izvršni tajnik Europskog udruženja za kriminologiju i redovni profesor Sveučilišta u Lausannei Marcelo Aebi, a nakon pozdravnog govora uslijedilo je svečano dodjeljivanje ESC-ovih nagrada. Nagradu za životni doprinos kriminologiji dobio je profesor emeritus Mike Hough, sa Sveučilišta u Londonu. Nagradu za ESC-ova mladog kriminologa ponio je doc. dr. sc. Rok Hacin za znanstveni rad "Prisoners' perceptions of legitimacy of prison staff in Slovenia" izdan 2018. godine u časopisu European Journal of Crime, Criminal Law and Criminal Justice. Najboljim znanstvenim radom objavljenom u časopisu European Journal of Criminology 2019. proglašen je "Determinants of reporting cybercrime: A comparison between identity theft, consumer fraud, and hacking", a nagradu su dobili autori Steve van de Weijer, Rutger Leukfeldt i Wim Bernasco. Nagradu za znanstvena dostignuća, za europskog kriminologa u ranoj fazi karijere dobio je profesor Wim Hardyns sa Sveučilišta u Ghentu. Kao

* Karlo Bojčić, asistent na Filozofskom fakultetu Sveučilišta Josipa Jurja Strossmayera u Osijeku, Lorenza Jägera 9, 31000 Osijek. E-adresa: kbojcic@ffos.hr. ORCID: https://orcid.org/0000-0001-7901-8833.

** Petra Šprem, asistent na projektu Pravnog fakulteta Sveučilišta u Zagrebu, Trg Republike Hrvatske 14, 10000 Zagreb. E-adresa: psprem@pravo.hr. ORCID: https://orcid.org/0000-0003-4396-6887.

*** Autori prikaza sudjelovali su na konferenciji u okviru CroViMo projekta (www.violence-lab.eu) i projekta "Projekt razvoja karijera mladih istraživača - izobrazba novih doktora znanosti” (ESF DOK-2018-01-6494 i DOK-2018-09- 6175), sufinanciranih od strane Hrvatske zaklade za znanost i Pravnog fakulteta Sveučilišta u Zagrebu te Europskog socijalnog fonda. Sudjelovanje na panelu Balkan Criminology ostvareno u okviru Balkan Criminology grupe uz potporu Resilience Funda - The Global Initiative Against Transnational Organized Crime (www.balkan-criminology.eu). 
priznanje za izvanredan doprinos u učinkovitom funkcioniranju Europskog kriminološkog društva nagradu su dobili profesori Martin Killias i David J. Smith. Posljednju nagradu za najbolju knjigu "Life imprisonment: A Global Human Rights Analysis" dobili su profesor emeritus Dirk van Zyl Smit i profesorica Catherine Appleton sa Sveučilišta u Nottinghamu. Nakon dodjele nagrada uslijedio je plenarni okrugli stol s temom kriminala, prava i društvenog poretka u doba pandemije, a na kojemu su govorili profesor Shin'ichi Ishizuka, član Izvršnog odbora Azijskog udruženja za kriminologiju; profesorica Tara McGee, predsjednica Udruženja za kriminologiju Australije i Novog Zelanda; profesor Dan Nagin, predsjednik Američkog udruženja za kriminologiju; te profesorica Sandra Walklate, predsjednica Britanskog društva za kriminologiju.

Drugog dana konferencije održana su dva panela u organizaciji ESC-ove radne grupe European Violence Monitor. U okviru ova dva panela devet članova istraživačke skupine projekta Hrvatski monitor nasilja - Violence Lab održalo je ukupno osam prezentacija. U fokusu oba panela bilo je nasilje, a izlagači su prikazali raznolikost fenomena nasilja poput seksualnog nasilja, nasilja u sportu, nasilja u zatvoru i nasilja među predškolskom djecom. Izložene prezentacije bavile su se i temom doprinosa socioloških teorija u objašnjenju etiologije nasilja, utjecajem medija tijekom pandemije na nasilje i probleme u ponašanju te fenomenom birokratskog elektroničkog zlostavljanja.

Prvim panelom naziva "On Sexual Violence, Violence in Sport and Prison Violence" predsjedao je izv. prof. dr. sc. Goran Livazović s Filozofskog fakulteta Sveučilišta Josipa Jurja Strossmayera u Osijeku, a nakon najave, panel je otvorio izv. prof. dr. sc. Igor Vuletić s Pravnog fakulteta Sveučilišta Josipa Jurja Strossmayera u Osijeku. Vuletić je govorio o novoj koncepciji seksualnih zločina uvedenoj u Kazneni zakon, koji je stupio na snagu 1. siječnja 2013. godine. Istaknuo je kako je reforma bila motivirana naporima zakonodavca za usklađivanjem s međunarodnim standardima, posebno onima postavljenim od Europske unije i Vijeća Europe. Istaknuta je i zanimljivost da tvorci novog Kaznenog zakona nisu slijedili uobičajeni njemački model, nego su se u slučajevima seksualnih zločina odlučili za engleski model. Ovaj novi koncept značajno proširuje kaznenu odgovornost za seksualne zločine, a kao primjer je navedena kriminalizacija nehajnih oblika silovanja i inkriminacija silovanja obmanom. Vuletić je istaknuo kako će biti zanimljivo vidjeti način na koji će hrvatski sudovi primijeniti novi model, a zatim je i naveo nekoliko primjera konkretnih slučajeva te istaknuo probleme primjene novog modela u njima.

Uslijedilo je izlaganje doc. dr. sc. Lucije Sokanović s Pravnog fakulteta Sveučilišta u Splitu na temu nasilja u i oko sporta, pri čemu je posebno istaknut problem nasilja na sportskim stadionima i njihovoj okolici. Sokanović je u prvom dijelu izlaganja istaknula uspjehe hrvatskog sporta i navela pozitivne primjere poput Dražena Petrovića, Janice Kostelić, Gorana Ivaniševića i Luke Modrića. Drugi dio izlaganja Sokanović je posvetila tamnoj strani medalje hrvatskog sporta, problemu nasilja i huliganizma. Istaknula je kako javne rasprave o kaznenoj odgovornosti u sportu često uključuju snažnu emocionalnu dimenziju pa čak i gađenje. Sokanović je zaključila kako, bez obzira na poseban Zakon o sprječavanju nereda na športskim natjecanjima i ostale pozitivne napore državnih vlasti kako bi osigurale mirno uživanje na sportskim priredbama, fenomen huliganizma i dalje opstaje te je iz tog razloga potrebna progresivna zakonska regulativa usmjerena na sprečavanje nasilja kao i dodatna izobrazba svih dionika u sportu. 
Tema nasilja u sportu dodatno je produbljena izlaganjem Petre Šprem s Pravnog fakulteta Sveučilišta u Zagrebu. Šprem je izlagala o boksu i ostalim kontaktnim sportovima koji su primjer ponašanja protivnom društvenim normama, a koji se toleriraju od strane pravnog sustava. U izlaganju je istaknut ambivalentan status boksa. Naime, iako je cilj ovog sporta fizički naštetiti drugoj osobi, on i dalje ima status olimpijskog sporta. Također, boks ima podršku mnogobrojne publike, ali je istodobno i zabranjen u pojedinim državama poput Norveške i Islanda. Šprem je istaknula kako se na pravnoj i kriminološkoj razini rijetko raspravlja o zahtjevima za ukidanje profesionalnog boksa, a tema nasilja u sportu zanemarena je u domaćoj i međunarodnoj stručnoj literaturi. Izlaganje je zaključila otvaranjem pitanja zašto društvo koje za cilj ima borbu protiv nasilja prihvaća i podržava sport koji je u suprotnosti s tim ciljem.

Panel je zatvoren temom nasilja u zatvoru, koju je izložila dr. sc. Reana Bezić s Pravnog fakulteta Sveučilišta u Zagrebu. U uvodnom dijelu izlaganja Bezić je istaknula kako je nasilje sastavni dio zatvorskog života, ali da se ono, s obzirom na kontekst i okruženje u kojem se događa, razlikuje od nasilja u svakodnevnom životu. Bezić je navela statistike pojedinih oblika nasilja u zatvoru poput nasilja prema zatvorskom osoblju, nasilja zatvorenika prema samome sebi te nasilja zatvorenika prema drugom zatvoreniku, koje je ujedno i najčešći oblik nasilja u zatvoru. U izlaganju je iznesen problem prenapučenosti zatvora, istaknuta je korelacija između broja zatvorenika i broja fizičkih sukoba zatvorenika te korelacija između broja zatvorenika i broja napada na službenu osobu. Izneseni su i drugi zanimljivi statistički podaci poput broja pokušaja samoubojstava i broja izvršenih samoubojstava u zatvoru, omjera čuvara i zatvorenika. Uz sve ove podatke, Bezić je istaknula i problem "tamne brojke" nasilja, odnosno procjene brojki realiziranog, ali neprijavljenog nasilja u okviru zatvorskog sustava.

Drugi panel naziva "New Trends in Understanding and Researching Violence" moderirala je doc. dr. sc. Lucija Sokanović s Pravnog fakulteta Sveučilišta u Splitu. Panel je otvoren prezentacijom sociologa, izv. prof. dr. sc. Marka Mrakovčića sa Pravnog fakulteta Sveučilišta u Splitu. Mrakovčić je ukazao na doprinose socioloških teorija u razumijevanju kriminaliteta, posebice nasilja. U prvom dijelu, Mrakovčić je istaknuo važnost sociologije i utjecaja kriminala na društvo te nužnost konstantne analize učinkovitosti kontrolnih mehanizama devijantnog ponašanja. Polazeći od pretpostavke da je kriminal društveni konstrukt i proizlazi iz društva te je vrednovan od strane društva, izlaganjem je predstavljena i jedna od poznatijih socioloških teorija koja nam može pomoći u razumijevanju (osobito etiologije) kriminala, a riječ je o teoriji anomije koja govori o tome da se kriminal pojavljuje kada u društvu ili nema adekvatnog pravnog ili izvanpravnog mehanizma kontrole ili kada isti ne funkcioniraju. Predstavljena je i teorija koja govori o utjecaju kulturnog okruženja na kriminal te o načinu na koji osobe katkad neutraliziraju moralnu disciplinu svog društvenog okruženja i racionaliziraju vlastito ponašanje pritom ga opravdavajući kao legitimno. Teorija etiketiranja također može biti važna u razumijevanju kriminala jer, kako navodi Mrakovčić, obilježavanje pojedinca kao delinkventnog od strane društva, pojačava njegovu samopercepciju o vlastitoj delinkventnosti i u nekim slučajevima ju može i potaknuti. Mrakovčić je izlaganje zaključio s naglašavanjem važnosti uloge sociologije u traženju uzroka kriminala, ali i izučavanju njegovih posljedica na društvo u cjelini.

Naredno izlaganje o aktualnoj temi utjecaja medijskog izvještavanja o pandemiji koronavirusa na razne aspekte života pojedinca, pa i na nasilje, održao je izv. prof. dr. sc. Goran Livazović s Filozofskog fakulteta Sveučilišta Josipa Jurja Strossmayera u Osijeku. Livazović je 
predstavio istraživanje na području RH kojem je bio cilj istražiti stvaraju li mediji kod ljudi "moralnu paniku”, odnosno povećavaju li kod pojedinaca percepciju o tzv. "svijet je zao" sindromu. U studiji je sudjelovao 461 sudionik. Rezultati su ukazali na stanovitu povezanost između medija i određenih stanja (npr. anksioznost) te ponašanja pojedinaca (npr. nasilničko ponašanje). Ipak, Livazović je naveo da istraživanje ukazuje na to da s jedne strane osobe koje učestalije koriste internet i druge medijske sadržaje pokazuju niži stupanj nasilničkog ponašanja, dok s druge strane izloženost većoj/manjoj količini informacija o COVID-19 pandemiji nema utjecaja na nasilničko ponašanja.

Pretposljednje izlaganje ovog panela, u suautorstvu izv. prof. dr. sc. Anna-Marie Getoš Kalac i Dalije Pribisalić s Pravnog fakulteta Sveučilišta u Zagrebu, osvrnulo se na noviju kriminološku temu koja je osobito izazovna na hrvatskom području i među hrvatskim znanstvenicima, odnosno voditeljima projekata (su)financiranih od strane Hrvatske zaklade za znanost (Zaklada). Autorice su prikazom preliminarnih rezultata istraživanja provedenih među voditeljima projekata (su)financiranih od strane Zaklade ukazale na poražavajući stupanj zadovoljstva i motiviranosti u znanstvenoj suradnji sa Zakladom, kao i na pronađene obrasce ponašanja koji ukazuju na sustavnu izloženost hrvatskih znanstvenika kibernetičkom zlostavljanju od strane bezlične birokracije. Osim što su ukazali na potrebu za detaljnijim istraživanjem ovog fenomena, rezultati istraživanja potaknuli su znanstvenu zajednicu na razgovor i početak suradnje radi rješavanja aktualnog problema.

Posljednja tema panela posvećena je fizičkom nasilju predškolske djece, a temu je izložio Karlo Bojčić s Filozofskog fakulteta Sveučilišta Josipa Jurja Strossmayera u Osijeku. Bojčić je u svojem izlaganju naveo najčešće oblike fizičkog nasilja među predškolskom djecom te se dotaknuo vječne dileme porijekla nasilja, odnosno je li ono nasljedno ili naučeno. Zatim su prikazani rezultati longitudinalnih epidemioloških istraživanja prema kojima se fizičko nasilje javlja već oko prve godine života, kada dijete stječe fizičku koordinaciju potrebnu za udaranje, guranje i grebanje. Istaknuto je da je vrhunac učestalosti fizičkog nasilja između 2. i 4. godine života, a nakon toga dolazi do opadanja učestalosti kod većine djece. Uslijedio je prikaz rizičnih čimbenika koji doprinose pojavi fizičkog nasilja kod djece, a koji su bili podijeljeni na individualne čimbenike, čimbenike u obitelji i čimbenike među vršnjacima. Zatim su navedene negativne posljedice te mogućnosti i oblici prevencije fizički nasilnog ponašanja. Izlaganje je završilo citiranjem švicarskog dječjeg psihijatra Boveta, prema kojemu prevencija treba biti usmjerena na pružanje podrške djevojčicama s problemima u ponašanju jer će one postati majke sljedeće generacije nasilnih dječaka.

Istoga dana održan je i znanstveni panel u okviru radne skupine ESC-a "Balkan Criminology" u suradnji s mrežom Global Initiative against Transnational Organized Crime (Global Initiative). Tematski, izlaganja na panelu fokusirala su se na najnovija istraživanja i inovativni pristup izučavanju organiziranog kriminala i korupcije na području jugoistočne Europe. Panel je moderirala izv. prof. dr. sc. Anna-Maria Getoš Kalac s Pravnog fakulteta Sveučilišta u Zagrebu, koja je ujedno i voditeljica uspješne istraživačke grupe "Balkan Criminology". Moderatorica je održala prvo izlaganje ovog panela u kojem je odmah u uvodnom dijelu ukazala na teorijske i praktične izazove definiranja i konceptualizacije organiziranog kriminala, "tamne brojke" ove vrste kriminaliteta te metodološke probleme službenih statistika u ovom području. Možebitno rješenje Getoš Kalac vidi u "spajanju točkica”: povezivanju i kombiniranju različitih pristupa, metodologija i izvora podataka koje bi pružile sveobuhvatan uvid u stvar- 
no stanje organiziranog kriminaliteta pri čemu bi glavni izvori podataka trebali obuhvaćati i rezultate znanstvenih istraživanja, informacije prikupljene od strane istraživačkih novinara, kaznene istrage, ali i izvješća nevladinih udruga. Getoš Kalac je ukazala i na dodatan izazov pri takvoj sinergiji različitih strana (znanstvenika, istraživačkih novinara, tijela kaznenog progona i nevladinih udruga), a odnosi se na njihove ciljeve koji ne moraju biti isti, pa stoga mogu utjecati i na brzinu prikupljanja informacija, drugačiju kvalitetu izvora, različitu metodologiju i valjanost podataka. Ipak, upozorava Getoš Kalac, svi sudionici moraju imati širu perspektivu i zajednički viši cilj, a to je razumijevanje i suzbijanje organiziranog kriminala te zbog toga, unatoč drugačijim polazištima, treba ustrajati na izgradnji povjerenja i njihovoj međusobnoj suradnji.

A koje su žarišne točke organiziranog kriminala na području zapadnog Balkana, u svom su izlaganju predstavili dr. Fabian Zhilla i dr. Walter Kemp iz mreže Global Initiative. Izlaganje se fokusiralo na lokalne ranjivosti u regionalnom kontekstu kroz izvješće izrađeno na temelju podataka koje je prikupilo 20 istraživača u šest zemalja zapadnog Balkana, a uključuje 350 intervjua s pravosudnim dužnosnicima, novinarima, predstavnicima civilnog društva i građana. Autori su naveli da razlozi zbog kojih neka mjesta mogu biti osjetljivija na organizirani kriminal uključuju ekonomsku ranjivost, slabo vodstvo, ali i lokaciju (poput međugraničnih prijelaza, tranzitnih ruta itd.), a dodatnu prepreku njegovu učinkovitom suzbijanju predstavlja i činjenica da su često lokalne kriminalne grupe pod okriljem političke zaštite zbog čega su "teže uhvatljive". U drugom dijelu izlaganja, autori su predstavili još jedno izvješće koje se temelji na znanstvenoj i stručnoj literaturi, medijskim člancima, službenim statistikama, ali i intervjuima s novinarima i pravosudnim dužnosnicima. Izvješće je ukazalo na nekoliko “žarišta” organiziranog kriminaliteta na svjetskoj razini, a to su: zapadne europske zemlje (pri čemu kriminalne grupe svoj fokus usmjeravaju u zemlje gdje postoji velika dijaspora, kao što su Italija, Njemačka i zemlje Beneluxa, dok su luke u Španjolskoj, Italiji, Nizozemskoj i Belgiji značajne ulazne zone), zemlje južne Afrike (koje je atraktivno okruženje za (i)legalni biznis s uhodanim financijskim sustavom i dobrom infrastrukturom, a i ključna je "žarišna točka" za rute trgovanja kokainom), Turska (u kojoj se često pakira i pohranjuje heroin, prije nego što se pošalje dalje - onečišćen, čime se postiže veći profit) te Latinska Amerika (gdje su balkanske grupe aktivne posljednjih nekoliko desetljeća i to kao važan faktor u posredovanju preprodaje droge). Važno je, zaključuju autori, da se ne podcjenjuje utjecaj i uloga balkanskih kriminalnih skupina na ilegalnim tržištima diljem svijeta, pri čemu je najvažnije da se uspostavi bolja međunarodnopravna suradnja, više zajedničkih istražnih operacija na čitavom području, bolja kontrola putovnica i prijelaza granica te saniranje ranjivosti pravosudnog sustava zemalja na Balkanu kako bi se spriječilo iseljavanje u druge zemlje.

Sljedeće izlaganje održao je ambasador iz mreže Global Initiative, dr. Uglješa Zvekić, koji je također govorio o glavnim izazovima organiziranog kriminala i korupcije na zapadnom Balkanu koji se u posljednje vrijeme premjestio u inozemstvo. Posebice, navodi Zvekić, zabrinjava činjenica da su kaznena djela korupcije često povezana s političkim establišmentom te da područje Balkana kronično pati od nedostatka neovisnih medija, organizacija civilnog društva koje bi se bavile suzbijanjem korupcije, istraživača i znanstvenika, ali i osjetljivosti građana. Ipak, upozorava Zvekić, zapadni Balkan je premalen za međunarodne organizirane kriminalne operacije, već služi za tranzitne rute i kao mjesto za pohranu i skrivanje. Izlaganjem je ukratko i predstavljen rad mreže Global Initiative koja je u veljači 2020. godine u Velikoj Britaniji održala sastanak upravo na temu organiziranog kriminala na području zapadnog Balkana i to 
u suradnji sa UNODC-om i Međunarodnim institutom za kazneno pravo i ljudska prava u Sirakuzi. Preporuke koje je iznjedrio spomenuti sastanak odnose se na bolju međunarodnu suradnju, jačanje civilnog sektora, snažnije zalaganje za zaštitu medijskih sloboda, bolja kontrola donacija političkim strankama, generalno jačanje pravosudnog sustava te kreiranje neovisne regionalne platforme za strategiju suzbijanja korupcije i organiziranog kriminaliteta.

Posljednje izlaganje ovog panela održala je doc. dr. sc. Sunčana Roksandić s Pravnog fakulteta Sveučilišta u Zagrebu. Docentica Roksandić izlaganje je počela predstavljanjem platforme The Berlin Process koja je s radom otpočela 2014. godine, a koja kroz olakšavanje regionalne suradnje među zemljama zapadnog Balkana ima za cilj uložiti zajedničke napore za veću sigurnost, stabilnost i prosperitet zemalja u regiji, pri čemu je borba protiv korupcije - prioritet. Tako je, navodi Roksandić, 2017. godine u Trstu potpisana zajednička deklaracija o navedenim ciljevima, pri čemu je ukupno šest zemalja usvojilo regionalni međunarodni sporazum o suzbijanju korupcije na ovom području. Sporazum je napisan na temelju glavnih zaključaka Summita o borbi protiv korupcije održanog 2016. godine u Londonu, prve globalne deklaracije protiv korupcije (GRECO), preporuka Europske komisije, ali i informacija i procjena nacionalnih eksperata, znanstvenika, istraživačkih novinara i organizacija iz civilnog sektora. U izlaganju Roksandić je izložila nekoliko ključnih zaključaka istraživanja: 1) premda postoje određene manjkavosti, zakonodavstvo zemalja u regiji prati europski acqui, 2) glavni izazovi su: manjak transparentnosti i problem pristupa javnim informacijama, pranje novca, korupcija u privatnom sektoru, financiranje političkih kampanja te 3) valjalo bi poraditi na javnom diskursu koji će podignuti svijest o štetnosti korupcije. Autorica je ukazala i na glavnu boljku organizirane korupcije visokog profila, a riječ je o političkoj korupciji (financiranje političkih stranaka, nepravilnosti u izborima i podmićivanje sudaca), pri čemu je osobit podstrek korupcije Hrvatska doživjela u razdoblju pretvorbe i privatizacije. Ipak, zaključno, Roksandić je završila u optimističnom tonu, podsjećajući da, unatoč nedostatku "kulture integriteta", u posljednjih pet godina zemlje regije pokazuju stanoviti napredak, a da bi on bio još brži, veoma je važno jačanje ekonomije, socijalna sigurnost i učinkovit pravosudni sustav. 